UDK 366.542:34(4-672EU:497.11)

https://doi.org/10.18485/union_pf_ccr.2021.ch17

Doc. dr Aleksa Radonjić*

\title{
SUDSKA ZAŠTITA KOLEKTIVNIH INTERESA POTROŠAČA U EVROPI. POUKE ZA PRAVO SRBIJE**
}

\begin{abstract}
Apstrakt: Budući da je usvajanje Direktive o predstavničkim tužbama za zaštitu kolektivnih interesa potrošača sasvim izvesno $i$ da je jedan od načina da se ona transponuje u pravo Srbije propisivanje posebnog parničnog postupka za sporove po takvim tužbama, autor skreće pažnju na nekoliko važnih pitanja koja bi trebalo rešiti kako bi to transponovanje bilo adekvatno i kako se ne bi ponovile greške iz 2011. godine. Autor tako ukazuje na specifičnu strukturu posebnog postupka, široka sudijska ovlašćenja u njemu, način određivanja subjektivnih granica pravosnažnosti presuda proisteklih iz tog postupka, neophodnost izmena odredaba o privremenim merama, a predlaže koncentraciju stvarne nadležnosti za rešavanje sporova po predstavničkim tužbama i daje razloge za to. Pre svega toga, autor daje pravnoekonomske $i$ bihevioralne argumente za kolektivnu zaštitu prava potrošača $i$ obrazlaže zašto novu tužbu treba nazvati predstavničkom.
\end{abstract}

Ključne reči: kolektivna zaštita potrošača, predstavnička tužba, opt-in, opt-out, kolektivni interesi potrošača.

\section{UVOD}

Imajući u vidu da je Srbija kandidat za članstvo u Evropskoj uniji (EU) i da već duži niz godina svoje zakonodavstvo usklađuje s pravnim tekovinama EU, kao i to da je sada već izvesno usvajanje Direktive EU o predstavničkim ${ }^{1}$ tužbama za zaštitu kolektivnih interesa potrošača (Direktiva), ${ }^{2}$ neminovno će se i pred zakonodavstvo Srbije postaviti zadatak da ovu direktivu transponuje u svoj pravni poredak.

* Docent na Pravnom fakultetu Univerziteta Union u Beogradu, e-mail: aleksa.radonjic@pravnifakultet.rs

** Rad je napisan kao rezultat istraživanja na naučnom projektu Pravnog fakulteta Univerziteta Union u Beogradu - Zaštita kolektivnih interesa potrošača u srpskom i uporednom pravu.

1 Više o ovom terminu odmah posle uvoda.

2 O tekstu Direktive je postignut politički dogovor i ostaje da se o njemu i formalno izjasne Savet i Parlament, posle čega treba da bude objavljen u Službenom glasniku EU kako bi postao važeći propis, što se u trenutku pisanja ovog rada još uvek nije dogodilo. Više videti na: https://www.europarl.europa.eu/news/en/press-room/20200619IPR81613/new-rules-alloweu-consumers-to-defend-their-rights-collectively, 24. 6. 2020. 
U uvodnoj izjavi broj 12 u Predlogu Direktive evropski zakonodavac pojašnjava da se državama ostavlja sloboda da odaberu da li će se o predstavničkim tužbama raspravljati pred sudovima ili pred nekim administrativnim telima. ${ }^{3}$ Kako se budućom direktivom države obavezuju da omoguće da se predstavničkim tužbama od nadležnog organa traži ne samo da utvrdi da je trgovac povredio neko pravo potrošača već i da obaveže trgovca na naknadu štete ili neku drugu radnju, kao što je umanjenje cene, popravka, raskid ugovora itd., tako je neophodno napomenuti da se termin „administrativna tela“ ne sme tumačiti tako da se radi o državnoj upravi jer bi to značilo poveravanje upravi sudskih ovlašćenja. To ne samo da nije u skladu sa Ustavom Republike Srbije, kojim je kao jedno od temeljnih načela propisano i načelo podele vlasti ${ }^{4}$, već se kosi i sa svrhom i samom strukturom upravnog postupka koji nije adversarijalan. Imajući u vidu uporednopravne primere, termin „administrativna tela“ koji je upotrebio evropski zakonodavac se odnosi na regulatorna tela koja često imaju kvazisudska ovlašćenja. ${ }^{5}$

U ovom radu ćemo se baviti sudskom zaštitom kolektivnih interesa potrošača. Razmotrićemo kako bi ona mogla da izgleda ako bi se naš zakonodavac odlučio da Direktivu (kada bude usvojena) transponuje tako što bi sudovima poverio rešavanje sporova koji bi bili pokretani predstavničkim tužbama. Pažnju ćemo posvetiti nekim odabranim pitanjima koja nameće Predlog Direktive u vezi sa sudskom zaštitom, jer bi detaljna analiza svakog člana zahtevala više od jednog članka. Jedno od najvažnijih je pitanje subjektivnih granica pravosnažnosti. Razmotrićemo određene osobenosti ovog parničnog postupka, skrenuti pažnju na neophodnost izmena postupka obezbeđenja i predložiti određivanje stvarne nadležnosti za ove sporove po ugledu na belgijsko rešenje. U tom cilju polazište je tekst buduće direktive, ali ćemo kao uzore konsultovati i UNIDROIT nacrt procesnih pravila o kolektivnoj zaštiti ${ }^{6}$, kao i rešenja iz Belgije i Slovenije, dva od nekoliko primera koji su poslužili kao inspiracija za taj nacrt. ${ }^{7}$ Pre svega toga smatramo da je neophodno raščistiti neka terminološka pitanja kako bi bilo jasno o čemu se zapravo govori kada je reč o predstavničkim tužbama, kao i pitanje svrhe ovog instituta.

3 Proposal for a DIRECTIVE OF THE EUROPEAN PARLIAMENT AND OF THE COUNCIL on representative actions for the protection of the collective interests of consumers, and repealing Directive 2009/22/EC, https://eur-lex.europa.eu/legal-content/EN/TXT/?uri=CELEX:52018PC0184, p. 20, 3. 7. 2020. (u daljem citiranju Proposal for a Directive on Representative Actions).

4 Član 4. Ustava Republike Srbije, Sl. glasnik RS, br. 98/06.

5 Više o ovome kod: Hodges, C., 2019, Collective Redress: The Need for New Technologies, Journal of Consumer Policy, 1, pp. 63-70.

6 European Law Institute (ELI) - International Institute for the Unification of Private Law (UNIDROIT), 2018, From Transnational Principles to European Rules of Civil Procedure. Presentation and discussion of the draft rules of the Working Group on 'Parties' (Collective Redress), https://www.europeanlawinstitute.eu/fileadmin/user_upload/p_eli/Projects/Unidroit_Materials/Trier_2018/WG_Parties_-_Draft_on_Collective_Redress.pdf, 3. 7. 2020.

7 European Law Institute (ELI), International Institute for the Unification of Private Law (UNIDROIT), 2018, p. 2. 


\section{2. ŠTA SU PREDSTAVNIČKE TUŽBE, ZAŠTO TAJ TERMIN I ČEMU SLUŽE?}

Postoje različiti modaliteti sudske kolektivne zaštite prava potrošača. Jedan takav je actio popularis koji u cilju zaštite određenog interesa može podneti svako bez obzira na to da li pripada grupi lica čiji se interesi žele tužbom zaštititi, ili joj ne pripada. ${ }^{8}$ Drugi model je class action koji podrazumeva da bilo koji član grupe čiji su interesi ugroženi ili prava povređena može podneti tužbu za zaštitu tih prava u ime cele grupe. ${ }^{9}$ Zatim, postoji „tužba ovlašćenog državnog ili paradržavnog organa“ da podnosi tužbe za zaštitu kolektivnih interesa. ${ }^{10}$ Kao što ime sugeriše, reč je o državnom organu ili regulatornom telu koji su zakonom ovlašćeni da pokreću sudske postupke za zaštitu prava određene grupe lica, na primer potrošača. Konačno, postoji i ono što profesorka Rakić-Vodinelić naziva organizacionom tužbom, ${ }^{11}$ a ja bih pre rekao organizacijska tužba. Kao što se iz naziva može naslutiti radi se o tužbi koju u ime grupe podnosi organizacija civilnog društva koja za cilj ima zaštitu prava te određene grupe. ${ }^{12}$

Predlogom Direktive predstavnička tužba je definisana kao tužba za zaštitu kolektivnih interesa potrošača, pri čemu potrošači nisu stranke u postupku koji se tom tužbom pokreće. ${ }^{13}$ Nadalje, iz Predloga Direktive se može videti da ovako opisane tužbe mogu podnositi samo kvalifikovani entiteti (qualified entities) koji su osnovani u skladu sa zakonom, neprofitnog su karaktera i čiji je legitimni interes poštovanje normi prava Unije na koje se Direktiva odnosi. ${ }^{14}$ Predlog Direktive obavezuje države da pitanje kvalifikovanog entiteta urede tako da potrošačke organizacije i regulatorna tela (independent public bodies) mogu imati status tog entiteta. ${ }^{15}$ Iz ovoga proizlazi da se evropski zakonodavac opredelio za kombinaciju tužbe ovlašćenog organa javne vlasti i organizacijske tužbe.

Otuda i prevod ovog instituta kao predstavničke tužbe. Naime, nemačka i hrvatska verzija Predloga Direktive govore o organizacijskim tužbama jer se u nemačkoj verziji koristi termin Verbandsklage, a u hrvatskoj udružna tužba. ${ }^{16}$ Međutim, u verzijama ovog dokumenta na engleskom i francuskom jeziku tužba o kojoj je reč se naziva representative action, odnosno action représentative, a na slovenačkom jeziku se ova tužba naziva zastopničkom. ${ }^{17}$ Imajući u vidu očiglednu nameru evropskog zakonodavca da procesnu legitimaciju ne pruži isključivo organizacijama za zaštitu prava potrošača već i u najmanju ruku organima javne

8

10 Ibid., str. 868.

11 Ibid., str. 869.

12 Ibid.

13 Art 3(4) Proposal for a Directive on Representative Actions.

14 Art 4(1) Proposal for a Directive on Representative Actions.

15 Art 4(3) Proposal for a Directive on Representative Actions.

16 Za verzije teksta Predloga Direktive na zvaničnim jezicima EU vid.: https://eur-lex.europa. eu/legal-content/SL/TXT/?uri=CELEX:52018PC0184, 3. 7. 2020.

17 Ibid. 
vlasti, jasno je da prevod ovog instituta kao organizacijske tužbe nije adekvatan. Takođe, iako slovenački prevod nudi precizniji termin, on može u našem pravnom sistemu voditi nedoumicama zbog već ustaljenog instituta pravnog zastupanja, pa deluje da je termin predstavnička tužba bolje rešenje.

Najzad, postavlja se pitanje čemu predstavnička tužba. Kao i svi mehanizmi zaštite kolektivnih interesa i predstavnička tužba ima za svrhu da olakša ostvarivanje kolektivnih interesa neke grupe lica, a u ovom konkretnom slučaju potrošača. Naime, ako se pogleda istraživanje koje je sprovela Evropska komisija u toku 2018. godine, može se videti da $22,5 \%$ potrošača u EU nije preduzelo ništa kada su njihova prava bila prekršena, a kao razlog za takvo pasivno držanje najčešće su isticali da bi trajalo predugo da ostvare svoja prava, da su iznosi za koje su bili oštećeni premali i nije bilo verovatno da bi došli do zadovoljavajućeg ishoda. ${ }^{18} \mathrm{U}$ literaturi se takođe napominje da potrošački sporovi najčešće jesu sporovi male vrednosti, ali da su troškovi takvih sporova visoki u poređenju sa očekivanom koristi ${ }^{19}$ od spora, naročito ako se u obzir uzme činjenica da uvek postoji makar i mali rizik da se spor izgubi, te da se za pojedinca u suštini ne isplati da se u spor upušta čak ni kada postoji velika izvesnost da je u pravu. ${ }^{20}$ Osim ekonomskih troškova, očekivano ili pretpostavljeno vreme trajanja spora, kao i druge neugodnosti koje parničenje donosi mogu potrošača dovesti do zaključka da jednostavno nije vredno truda boriti se, jer se ta vrsta troška ne može nadoknaditi čak ni kada se na sudu pobedi. ${ }^{21}$

Ako ekonomsku argumentaciju stavimo u domaći kontekst, videćemo da je situacija za potrošače u Srbiji povoljna. Naime, Zakon o zaštiti potrošača propisuje da se za potrošačke parnice u kojima vrednost predmeta spora ne prelazi 500.000 dinara ne plaća sudska taksa, kao i da udruženja i savezi udruženja, koji se bave zaštitom interesa potrošača mogu potrošače zastupati pred sudom. ${ }^{22}$ To je olakšica bez koje bi potrošači imali značajne troškove za ostvarivanje svojih prava sudskim putem. Tako, ako uzmemo radi jednostavnosti da je vrednost predmeta spora 10.000 dinara, ${ }^{23}$ da bi sastav tužbe i izlazak na ročište po advokatskoj tarifi potrošača koštali 13.500 dinara, ${ }^{24}$ sudska taksa za podnošenje

18 European Comission, Consumer Condition Score Board 2019 Edition, pp. 47-48, (https:// ec.europa.eu/info/sites/info/files/consumers-conditions-scoreboard-2019_en_1.pdf, 4. 7. 2020).

19 Misli se na naknadu štete, povraćaj novca, zamenu stvari i sl. a ne na koristi u smislu profita.

20 Nagy, C. I., 2019, Collective Actions in Europe A Comparative, Economic and Transsystemic Analysis, Szeged, Springer, pp. 11-13.

21 Ibid.

22 Član 140. stav 2. i član 135. stav 1. tačka 3. Zakona o zaštiti potrošača, Sl. glasnik RS, br. $62 / 14,6 / 16$ - dr. zakon i 44/18 - dr. zakon.

23 Imajući u vidu pisanje medija da se potrošači najčešće žale na kvalitet obuće, za vrednost predmeta spora uzeli smo iznos od 10.000 dinara budući da pojednostavljuje računicu i da se nalazi između cena prosečnih patika i cena prosečnih zimskih cipela. Što se tiče izveštaja medija videti na primer: https://www.rts.rs/page/stories/sr/story/125/drustvo/3354754/ najvise-reklamacija-na-obucu-kakva-su-prava-kupaca.html ili http://rs.nlinfo.com/Biznis/ a452898/NOPS-Potrosaci-u-Srbiji-se-najvise-zale-na-kvalitet-patika-i-telefona.html, 7.7 . 2020.

24 Izračunato prema Advokatskoj tarifi dostupnoj na: https://akb.org.rs/advokatska-tarifa/, 7. 7. 2020 . 
tužbe bi bila $1.900^{25}$ dinara, a to znači da bi potrošač i pre nego što bi znao ishod spora imao troškove od 15.400 dinara, i to ako se uzme da bi se spor okončao na jednom ročištu, što je malo verovatno, i da ne bi bilo potrebe za veštačenjem. Ako znamo da je medijalna neto zarada u aprilu 2020. godine iznosila 44.129 dinara ${ }^{26}$ to znači da bi, bez pomenutih odredaba Zakona o zaštiti potrošača, 50\% potrošača u Srbiji moralo da izdvoji više od trećine svoje zarade, i to samo da bi započelo postupak pred sudom, pri čemu je to iznos u idealnoj situaciji. Dakle, navedene ekonomske prepreke za ostvarivanje prava su u velikoj meri odredbama Zakona o zaštiti potrošača uklonjene jer se u najvećem broju slučajeva neće plaćati sudska taksa, a dostupna je besplatna stručna pomoć.

Ipak, ako se vratimo neekonomskim neugodnostima koje parničenje sa sobom nosi, kao i uvek prisutnom riziku da se spor izgubi, te da potrošač snosi troškove spora i s tim u vezi obratimo pažnju na to da je u bihevioralnoj psihologiji utvrđena sklonost ljudi da pridaju veći značaj potencijalnim gubicima naspram potencijalne dobiti (loss aversion), ${ }^{27}$ onda se može očekivati da će prosečan potrošač oklevati da se upusti u klasičan sudski postupak kako bi zaštitio svoja prava. Naročito ako potrošač očekuje da će suđenje trajati dugo i ako nema poverenje u pravosuđe. To bi moglo dati podsticaj nesavesnim trgovcima da krše prava potrošača kada postupaju po njihovim prigovorima, ili reklamacijama, ili da održavaju na snazi nepravične uslove poslovanja. Ovo je naročito moguće u sektorima tržišta gde ne postoji veliki broj takmaca kao što su u slučaju Srbije telekomunikacije ili prodaja tehničke robe.

Upravo bi ove probleme mogla da reši predstavnička tužba. Budući da je to po definiciji tužba koju podnosi ovlašćeni entitet u interesu potrošača koji sami nisu stranke u postupku, ${ }^{28}$ jasno je da taj entitet (npr. potrošačka organizacija) na sebe preuzima troškove vođenja spora, te i rizik od gubitka spora, kao i neekonomske neugodnosti parničenja, dok potrošači ne snose nikakve troškove, a u slučaju uspeha u parnici ostvaruju svoja prava. Tako su sve negativne strane ostvarivanja prava sa potrošača prebačene na teret kvalifikovanih entiteta čija je uloga zaštita interesa potrošača.

\section{PREDSTAVNIČKA TUŽBA PREMA PREDLOGU DIREKTIVE}

Predlogom Direktive je predviđeno da procesnu legitimaciju u sporovima po predstavničkim tužbama imaju kvalifikovani entiteti koje će na njihov zahtev države članice EU morati unapred da unesu na javno dostupnu listu takvih

25 Izračunato na osnovu člana 27. stava 1. tačke 2. i taksenoj tarifi Zakona o sudskim taksama, Sl. glasnik RS, br. 28/94, 53/95, 16/97, 34/01 - dr. zakon, 9/02, 29/04, 61/05, 116/08 - dr. zakon, 31/09, 101/11, 93/12, 93/14, 106/15 i 95/18.

26 https://www.stat.gov.rs/sr-latn/vesti/20200625-prosecne-zarade-po-zaposlenom-april-2020/, 7. 7. 2020.

27 Mathis, K., Steffen, A. D., From Rational Choice to Behavioral Economics: Theoretical Foundations, Empirical Findings and Legal Implications, in: Mathis, K. (ed.), 2015, European Perspectives on Behavioral Law and Economics Klaus), Cham, pp. 40-41.

28 Art 3(1) Proposal for a Directive on Representative Actions. 
entiteta. ${ }^{29}$ Da bi takav zahtev bio uvažen, entitet mora biti osnovan u skladu sa zakonom države članice, da ima za cilj zaštitu interesa potrošača i da je neprofitnog karaktera. ${ }^{30}$ Jednom registrovani entiteti mogu ovaj status izgubiti ako prestanu da ispunjavaju neki od ovih uslova. ${ }^{31}$ Konačno, države članice moraju obezbediti da regulatorna tela i organizacije potrošača imaju mogućnost da steknu status kvalifikovanog entiteta. ${ }^{32}$ Takođe, Direktiva dopušta da se određenim entitetima koji nisu na listi dodeli status kvalifikovanog entiteta za tačno određenu parnicu ako takav entitet ispunjava uslove za upis na listu kvalifikovanih entiteta. ${ }^{33}$ Dakle, ako npr. neka organizacija civilnog društva nije upisana na listu entiteta ovlašćenih da podnose predstavničke tužbe, a ispunjava uslove da na nju bude upisana, može joj se priznati procesna legitimacija. Međutim, ta legitimacija će važiti samo za taj jedan određeni slučaj. Da bi takva organizacija imala procesnu legitimaciju i za buduće sporove po predstavničkim tužbama, ona mora da se registruje.

Predlogom Direktive određuje se koja sve pravna sredstva procesno legitimisano lice mora imati na raspolaganju. Prema članu 5. Predloga Direktive, predstavničkom tužbom se može tražiti od suda da odredi prethodnu i privremenu meru kojom se tuženome naređuje da se sa određenom praksom ${ }^{34}$ prestane, ili ako se $s$ njom još nije otpočelo, ali je izvesno da će do nje doći, onda da se od takve prakse tuženi uzdrži; ili se može tražiti da sud donese deklaratorno rešenje kojim se utvrđuje da je određena praksa nezakonita, kao i da se $\mathrm{s}$ tom praksom mora prestati, odnosno da se $s$ njom ne sme ni početi. ${ }^{35}$ Prema istom članu Predloga Direktive kvalifikovani entitet ne mora prethodno da pribavi ovlašćenje od potrošača da bi upotrebio opisana pravna sredstva, a ne mora ni da dokaže da je bilo koji potrošač pretrpeo štetu, kao ni da je trgovac čija se praksa želi zabraniti postupao sa namerom ili nepažnjom..$^{36}$ Logično je da se postojanje štete ne mora dokazivati, budući da propisane mere imaju pre svega preventivnu funkciju, jer, kako je pokazano, omogućavaju da se traži zabrana prakse sa kojom trgovac još nije ni otpočeo. Takođe, može se raditi o aktuelnoj praksi trgovca zbog koje do štete po potrošača može doći tek u budućnosti. Na primer ako se radi o nepravičnim ugovornim odredbama, do štete će doći samo ako se dogodi slučaj u kojem se trgovac poziva na nepravičnu klauzulu, stoga je opravdano tražiti njenu zabranu ili njeno oglašavanje ništavom nezavisno od toga da li je njome neko oštećen ili nije.

Druga grupa mera koja se može zahtevati predstavničkom tužbom jesu mere koje bih uslovno rečeno nazvao restitutivnim jer svaka od njih u izvesnom smislu ima za cilj da potrošača dovede u situaciju u kojoj bi bio da za spor nije ni bilo po-

29 Art 4(1) Proposal for a Directive on Representative Actions.

$30 \quad$ Ibid.

31 Ibid.

32 Art 4(3) Proposal for a Directive on Representative Actions.

33 Art 4(2) Proposal for a Directive on Representative Actions.

34 Ovaj termin podrazumeva kako aktivne radnje, tako i propuštanja da se nešto učini. Vid. Art

3(5) Proposal for a Directive on Representative Actions.

35 Art 5 Proposal for a Directive on Representative Actions.

36 Ibid. 
voda. Tako su članom 6. Predloga Direktive države obavezane da procesno legitimisanim licima omoguće da predstavničkim tužbama traže od suda da obaveže tuženog da potrošačima između ostalog nadoknadi štetu, izvrši popravku, zameni proizvod ili umanji cenu, vrati novac, ili da zahtevaju raskid ugovora. ${ }^{37}$

Mogućnost isticanja tužbenih zahteva ove sadržine u tuđe ime neminovno nameće pitanje ko će biti obavezan presudom. Postoje dve krajnosti: presudom su obavezani samo oni potrošači koji su izričito na to pristali pre nego što je presuda doneta (opt-in), a drugo rešenje podrazumeva da presuda obavezuje sve potrošače koji su deo grupe potrošača koja je oštećena istim ili sličnim ponašanjem istog trgovca, osim ako izričito ne istupe iz grupe, tj. izjave da ne žele da budu obavezani presudom (opt-out). ${ }^{38}$ Ovo drugo rešenje je napadano da krši prava potrošača zagarantovana članom 6. Evropske konvencije za zaštitu ljudskih prava (Konvencija). ${ }^{39}$ Konkretno u takvim napadima se tvrdi da opt-out sistem potrošačima uskraćuje pravo da se izjasne o zahtevima, kao i pravo slobodnog raspolaganja svojim zahtevima ${ }^{40}$ Međutim, ovakvi argumenti su opovrgnuti i pred nacionalnim sudovima, ali i pred Evropskim sudom za ljudska prava. Primer za prvu tvrdnju može se naći u Holandiji gde je Apelacioni sud u Amsterdamu u slučaju Dexia naveo da se opt-out pravilom ne krše procesna prava potrošača ako su uredno ponaosob obavešteni o kolektivnoj tužbi i ako im je omogućeno da istupe iz grupe u čije ime se tužba podnosi, te da mogu da tuže u odvojenoj parnici u svoje ime. ${ }^{41}$ Što se tiče prakse Suda za ljudska prava u Strazburu (SzLJP), u literaturi se upućuje na slučaj Lithgow v. $U K{ }^{42} \mathrm{U}$ tom slučaju SzLJP je odlučio da se odredbama Zakona o nacionalizaciji, kojima je bilo propisano da u slučaju nacionalizacije kompanija deoničari mogu odabrati svog pravnog zastupnika ili da im se on može postaviti, te da je on ovlašćen da traži naknadu zbog nacionalizacije, čime su deoničari gubili mogućnost da to pravo pojedinčano ostvare, ne krše garancije iz člana 6 . Konvencije. ${ }^{43}$

Drugi argument protiv opt-out sistema je da će on dovesti do toga da se dosuđena odšteta, odnosno činidba nema kome isplatiti, odnosno izvršiti jer oni u čije ime se tuži nisu identifikovani. ${ }^{44}$ Ipak, ni ovaj argument u većini slučajeva ne stoji. Potrošači u čije ime se tuži najčešće su odredivi i na tako odredive grupe presuda i može glasiti; na primer može se odnositi na sve potrošače koji su ugovor sa tuženim potpisali u određenom vremenskom periodu. ${ }^{45}$ Naravno, kada grupu nije moguće dovoljno precizno odrediti, ostaje na raspolaganju $o p t$-in model kao alternativa.

Art 6 Proposal for a Directive on Representative Actions.

38 Mucha, J., 2019, Heading Towards an Effective Mechanism for the Protection of Collective Interests of Consumers - Some Comments on the Proposal for a Directive on Representative Actions, Yearbook of Antitrust and Regulatory Studies, 12, p. 208.

Voet, S., Belgium's New Consumer Class Action, in: Harsági, V., Rhee, C. H. van, (eds.), 2014, Multi-Party Redress Mechanisms in Europe: Squeaking Mice?, Cambridge, Intersentia, p. 100.

40 Nagy, C. I., 2019, p. 24.

41 Voet, S., 2014, p. 100.

42 Nagy, C. I., 2019, p. 26.

43 Ibid., pp. 26-27.

44 Ibid., p. 33.

45 Ibid., p. 34. 
S druge strane, empirijska istraživanja sugerišu da više potrošača biva obuhvaćeno dejstvom presude u opt-out sistemima nego u opt-in sistemima. ${ }^{46} \mathrm{Je}$ dan od razloga za to bi se opet mogao potražiti u bihevioralnoj psihologiji. Ona nas uči da ljudi teže održavanju trenutnog stanja (status-quo bias) čak i kada ih ništa ne bi koštalo da nešto promene, pri čemu bi nova situacija bila jednako dobra kao i postojeća. ${ }^{47} \mathrm{U}$ opt-in sistemu potrošači imaju transakcioni trošak promene sopstvene situacije, a to je registracija, tj. prijavljivanje, što podrazumeva nekakvu proceduru pa samim tim i gubitak vremena, dok u opt-out sistemu ne moraju preduzimati ništa da bi bili obuhvaćeni presudom. Bilo kako bilo opt-out dovodi do većeg obuhvata potrošača presudom što ide u korist zaštite prava potrošača, a tvrdi se da proizvodi veću pravnu sigurnost i za tuženog. ${ }^{48}$ To ima smisla budući da se širokim obuhvatom potrošača smanjuje mogućnost za nove parnice protiv tuženog u vezi s ponašanjem za koje je već tužen predstavničkom tužbom.

Evropski zakonodavac se u Predlogu Direktive nije dovoljno jasno odredio po pitanju opt-in ili opt-out. Naime, u uvodnoj izjavi broj 18 Predloga piše da kao uslov pokretanja postupka ne bi trebalo postavljati zahtev da kvalifikovani entiteti identifikuju sve potrošače ponaosob koji su kršenjem prava pogođeni. ${ }^{49} \mathrm{U}$ istoj uvodnoj izjavi se dodaje da kada se tužbom traže konkretna davanja ili činjena od tuženog, sud treba u najranijoj fazi postupka da oceni da li je slučaj takav da je podoban da se o njemu odlučuje po predstavničkoj tužbi. ${ }^{50}$ Ovo se može tumačiti kao opt-out. Međutim, pre može značiti da se izričit pristanak potrošača ne traži samo za podnošenje tužbe dok se to može zahtevati nakon što sud odluči da postupa dalje po predstavničkoj tužbi, dakle u nekoj kasnijoj fazi postupka. ${ }^{51} \mathrm{Da}$ lje, u članu 6. Predloga Direktive navodi se da država članica može kao uslov za donošenje odluke u postupku postaviti to da svaki potrošač lično da punomoć. ${ }^{52}$ Čini se ispravnim zaključak dat u literaturi da se na ovaj način prepušta državama članicama da same odaberu da li će primeniti opt-in, opt-out ili neku mešavinu jednog i drugog modela. ${ }^{53}$ Jedino u čemu je Predlog Direktive izričit, pored pomenutih postupaka u kojima se traži od suda da naredi da se trgovac od određene prakse uzdrži, jeste situacija u kojoj su potrošači pretrpeli toliko mali gubitak da bi bilo nesrazmerno težiti obeštećenju svakog potrošača, pa će se propisati da u tim situacijama ukupna suma odštete treba da se uplati u neku opštekorisnu svrhu koja će služiti kolektivnoj zaštiti potrošača, pa se u ovim slučajevima neće zahtevati pristanak potrošača da se parnica u njihovo ime vodi. ${ }^{54}$

Ibid., p. 17.

47 Tor, A., 2008, The Methodology of the Behavioral Analysis of Law, Haifa Law Review, 4, p. 264, (https://scholarship.law.nd.edu/law_faculty_scholarship/836, 26. 9. 2018).

48 Voet, S., 2014, p. 100.

49 Recital 18 Proposal for a Directive on Representative Actions.

50 Ibid.

51 Smith, V., 2019, Redress Through Collective Actions in Europe: ELI/Unidroit and European Commission Proposals, Uniform Law Review, 1, p. 8.

52 Art 6 Proposal for a Directive on Representative Actions.

53 Mucha, J., 2019, pp. 227-228.

54 Art 6(3)(b) Proposal for a Directive on Representative Actions. 
Ovo nerešeno pitanje subjektivnih granica pravosnažnosti moglo bi se rešiti tako što bi nacionalni sudovi u postupcima po predstavničkim tužbama donosili deklaratorne presude u kojima bi utvrđivali da je trgovac povredio određena prava potrošača, pa bi zatim potrošači pojedinačno podnosili tužbe kojima bi zahtevali konkretno činjenje od trgovca na osnovu tako utvrđene povrede. Međutim, buduća direktiva tu mogućnost ostavlja samo kao izuzetak od pravila koje nalaže da se o onome što sam nazvao restitutivnim zahtevima ima odlučivati već u postupku po predstavničkoj tužbi. ${ }^{55}$

U Predlogu Direktive se nalaže državama članicama da predvide mere koje će osigurati delotvornost postupaka po predstavničkim tužbama, kao i obavezu da postupak za određivanje privremene mere kojom se traži zabrana određene prakse trgovca urede kao postupak po ubrzanoj proceduri. ${ }^{56}$

Buduća direktiva daje malo ili nimalo uputstava kako tačno ove postupke urediti. Inspiraciju za rešavanje ovih pitanja valja potražiti u uporednom pravu. Pre svega mislim na Belgiju i Sloveniju, ali će u radu biti konsultovani i neki drugi uzori.

\section{OTVORENA PITANJA I NJIHOVA REŠENJA}

Na početku ovog dela valja sumirati koja su to otvorena pitanja. Prvo pitanje jeste opt-in ili opt-out ili nešto treće. Drugo pitanje tiče se strukture parničnog postupka, jer za koji god model da se odluči, radiće se o posebnom parničnom postupku. Treće pitanje jeste pitanje ubrzane procedure za određivanje privremenih mera. Tu je i pitanje stvarne nadležnosti za ovu vrstu sporova. To pitanje ne nameće Predlog Direktive, ali u uporednom pravu se može naći interesantno rešenje za koje nam se čini da je prirodno proisteklo iz odgovora na prethodna pitanja. Konačno, valja se setiti da je pokušaj da se uvede poseban parnični postupak za zaštitu kolektivnih prava i interesa iz 2011. godine propao. ${ }^{57}$ Naime, Ustavni sud je utvrdio da su odredbe Zakona o parničnom postupku kojima se uređuje poseban postupak za zaštitu kolektivnih prava i interesa neustavan između ostalog i zbog toga što pojam kolektivnih prava nije regulisan i što nema načina da se utvrdi na koje to sporove treba primeniti pravila ovog posebnog postupka. ${ }^{58}$ Stoga ćemo u pomenutim uzorima potražiti i rešenja ovog pitanja.

\subsection{OPT-IN ILI OPT-OUT ILI NEŠTO TREĆE?}

Ako se setimo argumenata iznetih u korist opt-out modela, ali i priznanja da nije uvek moguće primeniti ga, onda ne čudi što su se neke države odlučile da naprave kombinovani sistem. Zapravo, većina članica EU koje predviđaju po-

55 Vid. Art. 6(2) Proposal for a Directive on Representative Actions.

56 Vid. Art. 12 Proposal for a Directive on Representative Actions.

57 U Zakonu o parničnom postupku, Sl. glasnik RS, br. 72/11, glava XXXVI bila je posvećena postupku za zaštitu kolektivnih prava i interesa. Pojedina pravila te glave su oglašena neustavnim, pa se od celog postupka na kraju i odustalo. 
stupke po kolektivnim tužbama bar u određenoj meri dopušta i opt-out mehanizam. ${ }^{59}$ Dakle, deluje da je srednji put za sada dobro rešenje. Kao primer takvog mešanog sistema u literaturi se najčešće pominje Belgija.

U Belgiji je prepušteno sudijama da procene shodno konkretnim okolnostima slučaja da li je celishodnije primeniti opt-in ili opt-out model. ${ }^{60}$ Sud prvo odlučuje da li je slučaj takav da je bolje rešavati ga u okviru postupka po kolektivnoj tužbi, nego u klasičnom parničnom postupku. ${ }^{61}$ Sud odlučuje na osnovu niza kriterijuma kao što su veličina potencijalne grupe potrošača, postojanje štete nanete pojedincima u vezi s povredom kolektivnog interesa, da li će rešavanje po kolektivnoj tužbi doneti više pravne sigurnosti grupi potrošača u čije ime se tuži i da li će slučaj biti rešen efikasnije u takvoj proceduri. ${ }^{62}$ Ako odluči da je postupak kolektivne zaštite za konkretan slučaj bolji put od klasične parnice, onda sud donosi odluku da prihvata kolektivnu tužbu i u toj odluci precizira da li će se postupak dalje voditi po opt-out ili po opt-in sistemu, te će ostaviti rok potrošačima da daju izjavu da prihvataju da budu obuhvaćeni budućom presudom (opt-in), odnosno da to ne prihvataju (opt-out). ${ }^{63}$ Zakon obavezuje sud da primeni opt-in sistem kad se tužbom traži naknada nematerijalne štete, ili kada neki ili svi potrošači u čije ime se tuži nemaju prebivalište u Belgiji. ${ }^{64}$ Van toga nema propisanih kriterijuma koji bi sudijama pomogli kako da se odluče između ova dva mehanizma. Voet sugeriše da bi u slučajevima u kojima su članovi grupe pretrpeli individualno male iznose štete bilo pametno koristiti opt-out. ${ }^{65} \mathrm{Naža-}$ lost, nema sudske prakse koja bi upućivala na to kako sudovi u Belgiji procenjuju koji će od dva mehanizma i kada primeniti. ${ }^{66}$ Prema podacima iz 2018. godine, sud u Belgiji je do tada prihvatio samo jednu kolektivnu tužbu, odabrao je opt-in oblik, ali nije obrazložio svoj izbor. ${ }^{67}$

U Sloveniji je postupak sličan. Sud takođe ispituje da li je opravdano nastaviti sa postupkom po kolektivnoj tužbi, pa tek onda odlučuje na koji način će se odrediti grupa potrošača na koje će se presuda odnositi. Prvo pitanje sud rešava na osnovu niza kriterijuma od kojih skrećem pažnju na sledeće: $u$ tužbi se ističu slični zahtevi u ime odredive grupe lica, koji se tiču tih lica, sličnih ili povezanih pravnih i činjeničnih pitanja koja proističu iz istog slučaja masovne povrede i podobni su za kolektivnu zaštitu; zajednička pravna i činjenična pitanja prevladavaju nad pitanjima koja se tiču samo pojedinih članova grupe; grupa je toliko velika da bi rešavanje po pojedinačnim tužbama članova grupe ili upotrebom nekog drugog instituta kao što je suparničarstvo ili spajanje postupaka bilo manje delotvorno od

59 Nagy, C. I., 2019, pp. 73-75.

60 Voet, S., 2014, p. 100.

61 Ibid., p. 99.

62 Ibid.

63 Ibid., pp. 100-101.

64 Ibid.

65 Ibid., p 100.

66 Miklitz, H.-W., Saumier, G., Enforcement and Effecitveness of Consumer Law, in: Miklitz, H.-W., Saumier, G., (eds.), 2019, Enforcement and Effecitveness of Consumer Law, Cham, Springer, p. 20.

Ibid. 
rešavanja slučaja po kolektivnoj tužbi; tužbeni zahtev nije očigledno neosnovan; ako su dakle ovi uslovi ispunjeni, onda ima mesta kolektivnoj tužbi. ${ }^{68}$

Ako nađe da mesta kolektivnoj tužbi ima, onda će sud dalje odlučiti na koji način će se grupa formirati, da li po opt-in ili opt-out modelu. Tu odluku donosi vodeći se okolnostima konkretnog slučaja, a naročito vrednošću pojedinačnih zahteva članova grupe, kao i okolnostima koje su bile odlučujuće da se kolektivna tužba dopusti. ${ }^{69} \mathrm{Opt}$-in model će se primeniti ako se makar jedan zahtev u okviru grupe odnosi na nematerijalnu štetu ili ako najmanje $10 \%$ odštetnih zahteva prelazi vrednost od 2.000 evra. ${ }^{70}$ Kao i u Belgiji, opt-in će se uvek primeniti na ona lica koja nemaju prebivalište u Sloveniji. ${ }^{71}$

Imajući u vidu potencijalnu raznolikost slučajeva i veliki broj mogućih promenljivih činilaca teško je unapred propisati precizno kada treba primeniti opt-in, a kada opt-out režim. Zato se rešenje iz belgijskog i slovenačkog prava da se sudijama prepusti da o tome donesu odluku na osnovu okolnosti svakog slučaja čini najboljim mogućim. Međutim, čini nam se da bi ipak trebalo, kao pomoć sudijama u ovom ne tako lakom zadatku, jasnije formulisati i sumirati kriterijume za odabir metoda za formiranje grupe koja će biti obuhvaćena presudom. Čini nam se da bi pravilo iz Predloga Direktive kojim se propisuje da kada su potrošači na koje se tužba odnosi odredivi i kada su pretrpeli istu ili sličnu štetu uzrokovanu istim ponašanjem trgovca u odnosu na određeni vremenski period ili određenu kupovinu, da države članice ne mogu propisati da je uslov za podnošenje tužbe da kvalifikovani entitet ima ovlašćenje svakog pojedinačnog člana te grupe potrošača ${ }^{72}$ trebalo transponovati tako da ono obavezuje na opt-out, ali ne samo u inicijalnoj fazi postupka kako to sugeriše navedeno pravilo. Dakle, kada god je grupa odrediva, i kada članovi mogu od tuženog tražiti ista ili slična činjenja koja su proistekla iz istog događaja ili uzrokovana istom radnjom tuženog u određenom vremenskom periodu ili u odnosu na određenu kupovinu, onda se grupa treba formirati po opt-out modelu. To znači da će presudom biti obuhvaćeni svi oni potrošači koji pripadaju grupi shodno okolnostima slučaja koji izričito nisu izjavili da ne žele da se presuda na njih odnosi. Ovo pravilo naročito treba primeniti kada se radi o potraživanjima male vrednosti. Razlozi za to su već dati u drugom delu ovog rada. Ovo poslednje je izričito predviđeno i UNIDROIT model pravilima. ${ }^{73}$

S druge strane, bez obzira na odredivost, sličnosti i visinu odštetnog zahteva po predstavničkim tužbama, za naknadu nematerijalne štete valja primeniti opt-in model kako to sugerišu gore pomenuta pravila. U tim slučajevima, čak i kada je šteta prouzrokovana jednim istim aktom trgovca, ima značajnih razlika u činjenicama koje mogu biti suštinski važne za odluku o postojanju i stepenu štete i njenoj visini. ${ }^{74}$

68 Član 28. stav 4. Zakona o kolektivnih tožbah, Uradni list RS, št. 55/17.

69 Član 30. stav 1. Zakona o kolektivnih tožbah, Uradni list RS, št. 55/17.

70 Član 30. stav 2. Zakona o kolektivnih tožbah, Uradni list RS, št. 55/17.

71 Član 30. stav 3. Zakona o kolektivnih tožbah, Uradni list RS, št. 55/17.

72 Art. 6(3)(a) Proposal for a Directive on Representative Actions.

73 U pravilu X8(2)(a) European Law Institute (ELI) - International Institute for the Unification of Private Law (UNIDROIT), 2018, p. 16.

74 Smith, V., 2019, p. 5. 


\subsection{STRUKTURA POSEBNOG PARNIČNOG POSTUPKA ZA REŠAVANJE SPOROVA PO PREDSTAVNIČKIM TUŽBAMA}

Kao što se vidi već iz odeljka 4.1, struktura parničnog postupka za zaštitu kolektivnih interesa potrošača po predstavničkim tužbama je specifična. Prema svim uzorima ovde konsultovanim, ${ }^{75}$ prvi korak jeste ocena suda da li je slučaj podoban da se o njemu rešava u postupku zaštite kolektivnih interesa potrošača. Ako sud prihvati da na taj način postupa po predstavničkoj tužbi, on mora odrediti koji model će se primeniti i ostaviće rok da se zainteresovani potrošači prijave, odnosno odjave u zavisnosti od odabranog modela. Ostaviće i rok tuženom da odgovori na tužbu. Po proteku ovih rokova, sud prelazi na raspravu o predmetu spora.

Posebna pažnja se posvećuje i poravnanju. U sva tri modela se predviđa da postignut dogovor o poravnanju mora odobriti sud. Na primer u Sloveniji su izričito propisani razlozi koji obavezuju sud da odbije postignuto poravnanje i oni idu za tim da se obezbedi pravično zadovoljenje interesa potrošača, da se spreči zloupotreba mehanizma kolektivne zaštite za bogaćenje lica koja imaju procesnu legitimaciju itd. ${ }^{76}$

Dakle, ako se u Srbiji bude razmišljalo o uvođenju posebnog parničnog postupka za zaštitu kolektivnih interesa, on bi morao da bude detaljniji i složeniji od pokušaja iz 2011. godine.

\subsection{PRIVREMENE MERE}

Kao što smo već istakli na drugom mestu, jezik Zakona o izvršenju i obezbeđenju (ZIO) ${ }^{77}$ nije takav da može adekvatno da odgovori na izazove zaštite kolektivnih interesa. ${ }^{78}$ Naime, ZIO govori o obezbeđenju novčanih i nenovčanih potraživanja. ${ }^{79}$ Privremene mere kojima se želi zabraniti ili sprečiti praksa trgovca kojom se krše propisi o zaštiti prava potrošača nemaju za cilj da obezbede ispunjenje nekog konkretnog potraživanja, već da obezbede poštovanje propisa o zaštiti prava potrošača. Kao jedan od uslova za određivanje privremene mere ZIO navodi sprečavanje nenadoknadive štete, ali taj pojam vezuje za ostvarivanje potraživanja. ${ }^{80}$ Ovde se šteta sastoji u posledicama do kojih

75 Vid. Voet, S., 2014, pp. 95-107, European Law Institute (ELI) - International Institute for the Unification of Private Law (UNIDROIT), 2018 i Zakon o kolektivnih tožbah, Uradni list RS, št. 55/17.

76 Vid. član 17. Zakona o kolektivnih tožbah, Uradni list RS, št. 55/17.

77 Zakon o izvršenju i obezbeđenju, Sl. glasnik RS, br. 106/15, 106/16 - autentično tumačenje, $113 / 17$ - autentično tumačenje i 54/19.

78 Ovo sam napisao u kontekstu zaštite od ekoloških šteta, ali je stav jednako primenjiv na sve kolektivne interese, u tom smislu vid. Radonjić, A., Stjelja, I., 2018, Ekološka tužba - Pravo svih nas da zaštitimo životnu sredinu - Priručnik sa preporukama, Beograd, Beogradski centar za ljudska prava, str. 21.

79 Član 449. ZIO, Sl. glasnik RS, br. 106/15, 106/16 - autentično tumačenje, 113/17 - autentično tumačenje i $54 / 19$.

80 Član 449. stav 3. ZIO, Sl. glasnik RS, br. 106/15, 106/16 - autentično tumačenje, 113/17 -autentično tumačenje i 54/19. 
može dovesti kršenje propisa o zaštiti prava potrošača, na primer primenom nepravičnih ugovornih klauzula, primenom nepoštenih poslovnih praksi itd. Takvo ponašanje pogađa neodređeni ili širok krug lica i ne odnosi se na neko konkretno potraživanje. U tom smislu su od pomoći čl. 50. i 51. Zakona o kolektivnim tužbama Slovenije kojima je propisano da se kolektivna tužba kojom se traži zabrana određenog ponašanja trgovca može podneti kada on svojim opštim uslovima poslovanja, formularnim ugovorima, poslovnim praksama, oglašavanjem, ili na neki drugi način krši prava potrošača utvrđena propisima škodeći time njihovim kolektivnim interesima, kao i da se takav zahtev može istaći kao zahtev za određivanje privremene mere. ${ }^{81}$ Jezik ZIO je dakle „prilagođen dvostranačkom odnosu gde poverilac štiti lični interes, pa se i nenadoknadiva šteta vezuje za sudbinu potraživanja " 82 dok je smisao privremene mere na čije uvođenje obavezuje Direktiva o zaštiti kolektivnih interesa potrošača da se nezakonita praksa spreči ili zaustavi. Konačno, ZIO dozvoljava da se umesto privremene mere položi jemstvo. ${ }^{83}$ Ovu mogućnost treba izričito zabraniti u postupku za određivanje privremene mere čiji je cilj zaštita kolektivnih interesa potrošača, jer se svrha te mere može jedino ispuniti određenim činjenjem ili uzdržavanjem trgovca. Nikakva suma novca ne može zameniti taj zahtev za činjenjem ili nečinjenjem.

\subsection{POJAM KOLEKTIVNIH INTERESA POTROŠAČA}

Budući da je prethodni pokušaj da se u naše pravo uvede poseban parnični postupak za zaštitu kolektivnih interesa, između ostalog, propao i zbog toga što zakonodavac nije ni na koji način odredio pojam kolektivnih interesa, ${ }^{84}$ bilo bi dobro da se ovoga puta taj pojam definiše.

Članom 3(3) Predloga Direktive kolektivni interes potrošača je definisan kao interes više potrošača ${ }^{85} \mathrm{U}$ slovenačkom Zakonu o kolektivnim tužbama nema konkretne definicije pojma kolektivni interes, ali se iz različitih normi tog propisa može videti da se radi o interesima više lica koja su ugrožena ponašanjem ili aktom tuženog. ${ }^{86} \mathrm{U}$ hrvatskom Zakonu o parničnom postupku kolektivni interes je interes koji se odnosi na životnu sredinu, potrošačke interese itd. ${ }^{87}$ Dakle, u pitanju je definisanje navođenjem primera. Znatno preciznije kriterijume nudi Zakon o zaštiti potrošača Republike Srbije kojim je kolektivni interes potrošača definisan kao interes najmanje deset potrošača kojima je neko pravo povređeno

81 Zakon o kolektivnih tožbah, Uradni list RS, št. 55/17.

82 Radonjić, A., Stjelja, I., 2018, str. 21.

83 Član 451. ZIO, Sl. glasnik RS, br. 106/15, 106/16 - autentično tumačenje, 113/17- autentično tumačenje i 54/19.

84 Odulka Ustavnog suda br. IУ3-53/2012, str. 11.

85 Art. 3(3) Proposal for a Directive on Representative Actions.

86 Vid. npr. član 3. Zakona o kolektivnih tožbah, Uradni list RS, št. 55/17.

87 Članak 502.a Zakona o parničnom postupku Republike Hrvatske, Sl. list SFRJ, br. 4/77, $36 / 77,6 / 80,36 / 80,43 / 82,69 / 82,58 / 84,74 / 87,57 / 89,20 / 90,27 / 90,35 / 91$ i Narodne novine, br. 53/91, 91/92, 58/93, 112/99, 88/01, 117/03, 88/05, 02/07, 84/08, 96/08, 123/08, 57/11, 148/11, 25/13, 89/14, 70/19 - pročišćeni tekst. 
istim aktom ili ga je na isti način povredilo isto lice. ${ }^{88}$ Takođe, kolektivni interes potrošača je povređen i nezavisno od broja potrošača kada se radi o nepoštenoj poslovnoj praksi ili nepravičnim ugovornim klauzulama, kao i kada ponašanje trgovca može nepovoljno delovati na svakog potrošača koji bi se našao u takvoj činjeničnoj situaciji. ${ }^{89}$ Zakon izgleda prati jednu veoma dobro razvijenu definiciju koju nalazim kod profesorke Jovanić. ${ }^{90}$ Prema toj definiciji kolektivni interes potrošača postoji kada je „veći broj potrošača tangiran određenim ponašanjem ili se kršenje odvija u kontinuitetu“, pri čemu „mali broj kršenja propisa i prestanak ponašanja“ ne poništavaju postojanje kolektivnog interesa potrošača, kao i kada neka praksa trgovca utiče na svakog potrošača koji se nalazi u određenoj situaciji, odnosno kada određena praksa trgovca utiče na izuzetno važne interese potrošača poput zaštite života i zdravlja. ${ }^{11}$ Od duha te definicije Zakon odstupa samo kada određuje minimalni broj potrošača čiji interes mora biti povređen da bi se radilo o povredi kolektivnog interesa. Među državama koje predviđaju postupke zaštite kolektivnih interesa tesna većina država ne propisuje precizno neophodan broj potrošača čiji su interesi povređeni, već se drži odrednica „nekoliko“ ili „više“, a u Malti je „dva ili više“ ${ }^{92}$

Čini se da je određivanje bilo kojeg broja kao minimalnog arbitrarno. Smatramo da treba procenjivati od slučaja do slučaja kada se radi o povredi kolektivnih interesa potrošača. Broj potrošača pogođenih praksom trgovca svakako jeste jedan od kriterijuma, ali taj broj ne treba da bude uklesan u kamenu. Čini nam se da bi odrednica „više“ umesto konkretnog broja, uz druga dva kriterijuma na koje se upućuje u Zakonu o zaštiti potrošača, bila odlična definicija; dovoljno fleksibilna, a opet dovoljno precizna za upućivanje na to kada ima mesta upotrebi postupka za zaštitu kolektivnih interesa. Naime, Ustavni sud je kao nedopustivo naveo to što u relevantnim odredbama koje je oglasio neustavnim „nije uređeno kad jedan građanski spor ima karakter spora o kolektivnim pravima koji bi se rešavao po pravilima posebnog postupka[... “93 Taj problem bi se upravo mogao rešiti oslanjanjem na definiciju iz Zakona o zaštiti potrošača.

\subsection{STVARNA NADLEŽNOST}

Kada je u pitanju stvarna nadležnost za rešavanje kolektivnih sporova, u Belgiji postoji interesantno rešenje. Naime, za sporove po tužbama za zaštitu kolektivnih interesa potrošača nadležan je u prvom stepenu ili Prvostepeni sud u Briselu, ili Privredni sud u Briselu, dok po žalbama odlučuje Apelacioni sud u

88 Član 145. stav 1. tačka 1. Zakona o zaštiti potrošača, Sl. glasnik RS, br. 62/14, 6/16 - dr. zakon i $44 / 18$ - dr. zakon.

89 Član 145. stav 1. tačka 2. i stav 2. Zakona o zaštiti potrošača, Sl. glasnik RS, br. 62/14, 6/16 dr. zakon i 44/18 - dr. zakon.

90 Jovanić, T., Uloga uprave u zaštiti kolektivnih interesa potrošača, u: Bourgoignie, T., Jovanić, T., (ur.), 2013, Jačanje zaštite potrošača u Srbiji Liber amicorum Svetislav Taboroši, Beograd, Pravni fakultet Univerziteta u Beogradu, str. 316-317.

91 Ibid.

92 Nagy, C. I., 2019, pp. 88-95.

93 IУ 
Briselu. ${ }^{94}$ Argumenti za ovakvu koncentraciju stvarne nadležnosti u ovim stvarima su da to dovodi do iskusnog i efikasnog suda specijalizovanog za pitanja kolektivne zaštite, kao i do ujednačene i predvidive sudske prakse. ${ }^{95}$ Takođe se navodi da iskustvo pokazuje da nema mnogo slučajeva kolektivnih parnica u zemljama koje ovakav mehanizam poznaju, pa se čini neefikasnim nadležnost za malobrojne sporove u složenoj materiji dodeliti mnoštvu sudova u tako maloj državi poput Belgije. ${ }^{96}$

Imajući u vidu da Belgija ima nešto manje od 11.500 .000 stanovnika ${ }^{97}$ tim pre ista argumentacija važi i za Srbiju koja ima malo više od 7.200.000 stanovnika. ${ }^{98}$ Čini nam se da čak u našem slučaju nadležnost za sporove po predstavničkim tužbama treba poveriti ili Višem sudu u Beogradu i Apelacionom sudu u Beogradu, ili Privrednom sudu u Beogradu i Privrednom apelacionom sudu. Kriterijum za odabir između ove dve varijante bi mogao da bude opterećenje ovih sudova, pa bi nadležnost trebalo poveriti manje opterećenom paru. Beograd smo naveli zbog toga što je najveći ekonomski centar u zemlji, pa bi se na osnovu toga moglo očekivati da ovi sudovi imaju i iskusnije sudije, što naravno ne mora biti tačno.

Kako se ovde radi o kompleksnom postupku u kojem sudije imaju dosta toga da procenjuju i pre nego što počnu da razmišljaju o samom predmetu spora, bilo bi neophodno sprovesti obuku sudija. Kada se ima u vidu da se u više zemalja kao jedna od prepreka u ostvarivanju prava potrošača pred sudovima navodi to da sudije nedovoljno poznaju potrošačko pravo, kao i da Srbija spada u tu grupu zemalja, ${ }^{99}$ onda ova koncentracija nadležnosti u dva suda u zemlji ima smisla i iz ugla efikasnosti neophodne obuke sudija.

\section{ZAKLJUČAK}

Usvajanje Direktive EU kojom se uvode predstavničke tužbe za zaštitu kolektivnih interesa potrošača je sasvim izvesno. Stoga će i Srbija na svom putu pridruživanja EU imati obavezu da ovu direktivu transponuje u svoje zakonodavstvo. Jedan od mogućih načina da se to uradi jeste propisivanje posebnog parničnog postupka za zaštitu kolektivnih interesa potrošača.

Ako se domaći zakonodavac odluči na takav korak, onda bi bilo važno da ne ponovi greške iz 2011. godine i da izvuče neke pouke iz uporednog prava u vezi s tim kako bi taj postupak trebalo da izgleda. U tom smislu u ovom radu je istaknuto nekoliko (od mnogih) karakteristika ovog postupka. Njegova struktura je drugačija i potrebno je predvideti jednu fazu u kojoj će sud ispitivati da li je u konkretnom slučaju celishodnije o njemu raspravljati u tom posebnom postup-

94 Voet, S., 2014, p. 99.

95 Ibid.

96 Ibid.

97 https://statbel.fgov.be/en/themes/population/structure-population, 20. 7. 2020.

98 https://www.stat.gov.rs/sr-Latn/oblasti/stanovnistvo/procene-stanovnistva, 20. 7. 2020.

99 Miklitz, H.-W., Saumier, G., 2019, p. 19. 
ku ili u redovnom parničnom postupku. Ako se sud odluči da se slučaj raspravi u posebnom postupku, na njemu je da odluči na osnovu nekoliko propisanih smernica da li će se subjektivne granice pravosnažnosti buduće presude iscrtati pomoću modela prijave (opt-in) ili modela odjave (opt-out), kao i da ostavi odgovarajući rok potrošačima da se prijave, odnosno odjave. Važno je i odrediti kada to ima mesta primeni ovog posebnog postupka, pa se u radu upućuje na definiciju iz Zakona o zaštiti potrošača Srbije kao adekvatnu, uz jednu malu izmenu u vezi s minimalnim brojem potrošača kao elementom definicije kolektivnog interesa potrošača. Skrenuta je i pažnja na neophodnost dopuna odredaba o privremenim merama, jer sadašnji tekst ZIO u tom pogledu ne prepoznaje specifičnost privremenih mera na čije uvođenje obavezuje buduća direktiva. Najzad, zbog složenosti ovog postupka koja rađa potrebu za obukom sudija, ali i ujednačenom sudskom praksom, smatrao sam da je pametno poveriti stvarnu nadležnost za rešavanje sporova po predstavničkim tužbama jednom sudu u prvom stepenu i jednom sudu u drugom stepenu za teritoriju cele države. Za takvu koncentraciju stvarne nadležnosti našli smo argument u pravu Belgije.

Ne manje važno, u radu smo odredili i kojim terminom bi trebalo prevesti naziv tužbe na čije uvođenje u naše pravo obavezuje buduća direktiva i obrazložili smo zašto baš taj termin: predstavnička tužba.

\section{LITERATURA}

1. Hodges, C., 2019, Collective Redress: The Need for New Technologies, Journal of Consumer Policy, 1.

2. Jovanić, T., Uloga uprave u zaštiti kolektivnih interesa potrošača, u: Bourgoignie, T., Jovanić, T., (ur.), 2013, Jačanje zaštite potrošača u Srbiji Liber amicorum Svetislav Taboroši, Beograd, Pravni fakultet Univerziteta u Beogradu.

3. Mathis, K., Steffen, A. D., From Rational Choice to Behavioral Economics: Theoretical Foundations, Empirical Findings and Legal Implications, in: Mathis, K., (ed.), 2015, European Perspectives on Behavioral Law and Economics, Cham.

4. Miklitz, H.-W., Saumier, G., Enforcement and Effecitveness of Consumer Law, in: Miklitz, H.-W., Saumier, G., (eds.), 2019, Enforcement and Effecitveness of Consumer Law, Cham, Springer.

5. Mucha, J., 2019, Heading Towards an Effective Mechanism for the Protection of Collective Interests of Consumers - Some Comments on the Proposal for a Directive on Representative Actions, Yearbook of Antitrust and Regulatory Studies, 12.

6. Nagy, C. I., 2019, Collective Actions in Europe A Comparative, Economic and Transsystemic Analysis, Szeged, Springer.

7. Radonjić, A., Stjelja, I., 2018, Ekološka tužba - Pravo svih nas da zaštitimo životnu sredinu - Priručnik sa preporukama, Beograd, Beogradski centar za ljudska prava.

8. Rakić-Vodinelić, V., 1989, Ekološka tužba, Pravni život, 4/5.

9. Smith, V., 2019, Redress Through Collective Actions in Europe: ELI/Unidroit and European Commission Proposals, Uniform Law Review, 1.

10. Tor, A., 2008, The Methodology of the Behavioral Analysis of Law, Haifa Law Review, 4. 
11. Voet, S., Belgium's New Consumer Class Action, in: Harsági, V., Rhee, C. H. van, (eds.), 2014, Multi-Party Redress Mechanisms in Europe: Squeaking Mice?, Cambridge, Intersentia.

\section{PROPISI, PREDLOZI I MODELI PROPISA}

1. Proposal for a DIRECTIVE OF THE EUROPEAN PARLIAMENT AND OF THE COUNCIL on representative actions for the protection of the collective interests of consumers, and repealing Directive 2009/22/EC

2. Ustav Republike Srbije, Sl. glasnikRS, br. 98/06.

3. Zakon o parničnom postupku, Sl. glasnik RS, br. 72/11.

4. Zakon o izvršenju i obezbeđenju, Sl. glasnik RS, br. 106/15, 106/16 - autentično tumačenje, 113/17 - autentično tumačenje i 54/19.

5. Zakon o zaštiti potrošača, Sl. glasnik RS, br. 62/14, 6/16 - dr. zakon i 44/18 - dr. zakon.

6. Zakon o kolektivnih tožbah, Uradni list RS, št. 55/17.

7. Zakon o parničnom postupku Republike Hrvatske, Sl. list SFRJ, br. 4/77, 36/77, 6/80, 36/80, 43/82, 69/82, 58/84, 74/87, 57/89, 20/90, 27/90, 35/91, i Narodne novine, br. 53/91, 91/92, 58/93, 112/99, 88/01, 117/03, 88/05, 02/07, 84/08, 96/08, 123/08, 57/11, 148/11, 25/13, 89/14, 70/19 - pročišćeni tekst.

8. European Law Institute (ELI) - International Institute for the Unification of Private Law (UNIDROIT), 2018, From Transnational Principles to European Rules of Civil Procedure. Presentation and discussion of the draft rules of the Working Group on 'Parties' (Collective Redress).

9. Advokatska tarifa, (https://akb.org.rs/advokatska-tarifa/, 7. 7. 2020).

10. Zakon o sudskim taksama, Sl. glasnik RS, br. 28/94, 53/95, 16/97, 34/01 - dr. zakon, 9/02, 29/2004, 61/2005, 116/2008 - dr. zakon, 31/09, 101/11, 93/12, 93/14, 106/15 i $95 / 18$.

\section{SUDSKA PRAKSA}

1. $\mathrm{IY}_{3}-53 / 2012$

\section{DRUGI IZVORI}

1. New rules allow EU consumers to defend their rights collectively, Europan Parliament Press Releases, (https://www.europarl.europa.eu/news/en/pressroom/20200619IPR81613/new-rules-allow-eu-consumers-to-defend-their-rights-collectively, 24. 6. 2020).

2. European Comission, Consumer Condition Score Board 2019 Edition, (https:// ec.europa.eu/info/sites/info/files/consumers-conditions-scoreboard-2019_en_1.pdf, 4. 7. 2020).

3. „Najviše reklamacija na obuću“, RTS, (https:/www.rts.rs/page/stories/sr/story/125/ drustvo/3354754/najvise-reklamacija-na-obucu-kakva-su-prava-kupaca.html, 7.7. 2020).

4. „Potrošači se najviše žale na kvalitet patika i telefona“, N1, (http://rs.nlinfo.com/Biznis/a452898/NOPS-Potrosaci-u-Srbiji-se-najvise-zale-na-kvalitet-patika-i-telefona. html, 7. 7. 2020). 
5. Podaci o medijalnoj zaradi, Republički zavod za statistiku, (https://www.stat.gov.rs/ sr-latn/vesti/20200625-prosecne-zarade-po-zaposlenom-april-2020/, 7. 7. 2020).

6. Podaci o broju stanovnika u Belgiji, Federalna služba za statistiku, (https://statbel. fgov.be/en/themes/population/structure-population, 20. 7. 2020).

7. Podaci o broju stanovnika u Srbiji, Republički zavod za statistiku, (https://www.stat. gov.rs/sr-Latn/oblasti/stanovnistvo/procene-stanovnistva, 20. 7. 2020).

\title{
JUDICIAL PROTECTION OF COLLECTIVE CONSUMER INTERESTS IN EUROPE. LESSONS FOR SERBIAN LAW
}

\author{
Aleksa Radonjić \\ SUMMARY
}

Starting from the fact that the enactment of the Proposal for the Directive of the European Parliament and of the Council on representative actions for the protection of the collective interests of consumers is quite certain the goal of this paper is to shed a light on several important issues that will arise should the Serbian legislator decide to transpose this Directive by instituting a new special judicial procedure.

The author gives brief overview of the structure of such a procedure, argues for a specific combination of $o p t$-in and opt-out models of forming the group, underlies the necessity to amend the interim measures rules, suggests the designation of the notion of consumer collective interests, and argues for the concentration of jurisdiction to trial disputes on representative actions which could result in specialized court for this particular procedure, unified caselaw and consequently high legal certainty for all the parties, as well as possibility to conduct effective training of the judges. For these arguments the primary sources of inspiration were Belgian and Slovenian laws on collective redress, as well as UNIDROIT model rules.

Before these specific issues are tackled, the author gives law and economics, and behavioral arguments for the introduction of collective redress mechanism for consumer disputes, and also explains the terminological issues arising from the transposition of this novel instrument into the law of Serbia.

Key words: consumer collective redress, representative action, opti-in, opt-out, collective interests of consumers. 